\title{
Margaret McCartney: Trust has to be earned
}

\author{
Margaret McCartney general practitioner
}

Glasgow

The NHS is a brand beyond advertising. The British public are proud of it and trust it more than any other institution, ${ }^{1}$ and $90 \%$ support its founding values. ${ }^{2}$ Some of this is a genuine, deep emotional bond; some is a loving tolerance despite its struggles and failings.

The NHS has also provided the British public with an absence of something. Not having to worry about accessing healthcare when we need it. Not fretting over policy documents and expiry dates or about adding new conditions to our coverage. When we sleep at night, the fear of getting the healthcare we need doesn't prey on us. And we expect that our trust is repaid-that our data are stored confidentially, that we will be treated with courtesy, and that mistakes or errors will be owned up to. Even if much of the way healthcare is organised and delivered is devolved across the four nations of the UK, the NHS provides a security that my generation has always known.

The NHS has also provided the British public with an absence of something: not having to worry

These are some of the reasons why the case of Albert Thompson induces disquiet. He arrived from Jamaica as a teenager. His mother was a nurse. Thompson, who has never applied for a British passport, worked and brought up his children here. Then, at age 63 , he was told by the Royal Marsden Hospital that he needed to either pay over $£ 50000$ up front or give proof of his residency before he could be treated for prostate cancer. The documentation he has doesn't satisfy the Home Office, and his lawyers are aware of several similar cases. ${ }^{3}$

What does this mean now for the children of immigrants? Can they feel ease that they're protected under the umbrella of the NHS — or frightened that they're excluded from it?
Trust is hard to earn and easy to lose, and we diminish the need for it at our peril. We see fundamental differences of opinion on the role of NHS Digital in terms of data sharing with the Home Office. NHS Digital feels justified in supplying information to the Home Office despite not being legally compelled to do so-distinct from its responsibilities for assisting the police with serious crime. ${ }^{4}$ Many organisations have spoken out about their concerns on how this will adversely affect vulnerable groups. ${ }^{5}$

We can feel no ease with giving our health data to a system that doesn't understand that we need to trust it to be confidential. This trust in the NHS is a moral one, where we're willing to tolerate imperfections and to work harder than we're contracted to, because we know that the underlying case for it is one to admire and aspire to. As the UK appears to harden its stance on immigration, the case for applying the founding standards of humanity and compassion to today's NHS gets stronger.

Competing interests: See www.bmj.com/about-bmj/freelance-contributors/margaretmccartney.

Provenance and peer review: Commissioned; not externally peer reviewed.

1. Mann J. Britain Uncovered survey results: the attitudes and beliefs of Britons in 2015. Guardian 19 April 2015. https://www.theguardian.com/society/2015/apr/19/britainuncovered-survey-attitudes-beliefs-britons-2015.

King's Fund. What does the public think about the NHS? 16 Sept 2017. https://www. kingsfund.org.uk/publications/what-does-public-think-about-nhs.

3 Gentleman A. Londoner denied NHS cancer care: "It's like I'm being left to die." Guardian 10 March 2018.

4 Health and Social Care Committee. 15/3/18 session with Sarah Wilkinson and Noel Gordon (NHS Digital). ParliamentLive 15 March 2018. www.parliamentlive.tv/Event//ndex/ 59bde96c-5aa7-42f5-8560-ad8b1d18e700.

5 Hill R. UK.gov slammed for NHS data deal with Home Office. Register 17 Jan 2018. https: //www.theregister.co.uk/2018/01/17/nhs_data_sharing_immigration_slammed/.

Published by the BMJ Publishing Group Limited. For permission to use (where not already granted under a licence) please go to http://group.bmj.com/group/rights-licensing/ permissions 